\title{
Enzymatic hydrolysis of carbohydrates in by-products of processed rice
}

\author{
Camila da Silva Turini ${ }^{1^{*}}$ (D) Roberta Martins Nogueira ${ }^{2}$ (D) \\ Evaldo Martins Pires $^{2}$ (D) Juliana da Silva Agostini ${ }^{2}$ (i)
}

\author{
1nstituto de Ciências da Saúde, Universidade Federal de Mato Grosso (UFMT), 78557-267, Sinop, MT, Brasil. E-mail: camilaturini07@gmail.com. \\ ${ }^{*}$ Corresponding author. \\ ${ }^{2}$ Universidade Federal de Mato Grosso (UFMT), Sinop, MT, Brasil.
}

\begin{abstract}
Over post-harvest steps of rice, from pre-cleaning to processing, a large amount of by-product is generated. Some of these byproducts, due to their high starch and fiber content can be used in ethanol production. The objective was to evaluate the effect of enzymatic hydrolysis conditions on the production of reducing sugars, from pre-cleaning residue and type III paddy rice, as well as the effect of the pretreatment of its fibers, targeting the use of these residues in ethanol fuel production. The proximate analysis was performed, followed by the pre-treatment of samples. Enzymatic hydrolysis was conducted in two ways: using one enzyme at a time or applying them simultaneously. The starch content was 41.18 and $53.41 \%$; the fibers were 30.44 and $23.39 \%$, of which 6.53 and $4.41 \%$ were lignin, for the pre-cleaning residue and paddy rice, respectively. Alkaline pre-treatment reduce lignin content by 47.94 and $18.23 \%$ for the pre-cleaning residue and type III paddy rice, respectively. Hydrolysis efficiency was 22.61 and $15.32 \%$ for the cellulase enzyme, and 82.18 and $87.07 \%$ for the amylolytic enzymes in the pre-cleaning residue and type III paddy rice, respectively. The hydrolysis with the separated enzymes presented higher reducing sugar yields. Therefore, the pre-cleaning residue and type III paddy rice can be used for ethanol production by its enzymatic hydrolysis, aiming to add value and to increase the sustainability of the rice production chain.
\end{abstract}

Key words: enzyme, Oryza sativa, reducing sugar, residue, starch.

Hidrólise enzimática de carboidratos em coprodutos do arroz beneficiado

RESUMO: Durante o processamento do arroz são gerados grandes volumes de residuos, desde a pré-limpeza até o beneficiamento. Alguns destes resíduos, por apresentarem elevado teor de amido e fibras, podem ser utilizados na produção de etanol. O objetivo foi avaliar a viabilidade técnica do resíduo da pré-limpeza e do arroz em casca tipo III como matéria-prima para a produção de etanol, a partir da hidrólise enzimática. Foi analisada a composição centesimal dos resíduos e, em seguida, o pré-tratamento. A hidrólise enzimática foi realizada por dois procedimentos, o primeiro com as enzimas separadas e o segundo com as enzimas atuando simultaneamente. $O$ teor de amido foi de 41,18 e 53,41\%; de fibras 30,44\% e 23,39\%, dentre as quais 6,53 e 4,41\% foi de lignina, para o residuo da pré-limpeza e o arroz em casca, respectivamente. Com o pré-tratamento alcalino, a lignina reduziu em 47,94 e 18,23\% para o resíduo da pré-limpeza e para o arroz em casca tipo III, respectivamente. A eficiência da hidrólise foi de 22,61 e 15,32\% para a enzima celulase, e 82,18 e 87,07\% para as enzimas amilolíticas no resíduo da pré-limpeza e no arroz em casca tipo III, respectivamente. A hidrólise com as enzimas separadas apresentou maior rendimento em açúcar redutor. Sendo assim, o resíduo da pré-limpeza e o arroz em casca do tipo III podem ser considerados matérias-primas viáveis para produção de etanol, visando agregação de valor e o aumento da sustentabilidade na cadeia produtiva do arroz.

Palavras-chave: açúcar redutor, amido, enzima, Oryza sativa, resíduo.

\section{INTRODUCTION}

Oryza sativa (rice) is one of the most important cereals for the food chain. Brazil is the $9^{\text {th }}$ largest producer in the world and the largest in Latin America, having produced 11.4 million tons during the 2018 harvest (FAO, 2018; IBGE, 2019).

The grains are composed of proteins, lipids, fibers, ashes, minerals, vitamins and starch. The latter represents the largest amount in the grain composition (WALTER, et al., 2008; ZIEGLER et al., 2017). Factors such as cultivar, soil preparation, seed quality, climate, storage conditions and harvest time can influence the composition, yield and quality of the grain (KAMINSKI et al., 2013; ZIEGLER et al., 2017).

Before it is marketed, polished rice undergoes pre-cleaning, drying, storage, classification and processing operations inside a processing plant. During the pre-cleaning phase, impurities such as straw, husks, broken grains, stones and other materials are removed. Impurities can slow down 
the drying process, accelerate the development of microorganisms, and facilitate insects' proliferation (HALBERSTADT et al., 2015). From field to market, about 2 million tons of by-products are generated annually in Brazil (IPEA, 2012). Some of them are currently used for animal feed or energy production.

Domestic and International markets have requirements for paddy or processed grain, as well for its fragments. For the Brazilian market, the Normative Instruction number 6 of 2009, from the Ministry of Agriculture, Livestock and Supply (BRASIL, 2009) defines classes based on the grain quality. Rice is classified according to the occurrence of defects, from type I to non-compliant. Lower quality rice has a reduced market value, which may turn its processing unfeasible.

Thus, by-products or low-quality grains can become a co-product, considering the development of technologies that can use it alternatively, adding value to the production chain (NASCIMENTO FILHO \& FRANCO, 2015).

The transformation of by-products from agricultural raw materials processing has been widely studied, emphasizing biofuel production, that can enhance profits of the production chains and its sustainability, not to mention that the by-products may not compete with food production (NONES et al., 2017; TAKANO \& HOSHINO, 2018). Brazil stands out as one of the largest ethanol producers in the world, having produced approximately 33.14 billion liters in the 2018/2019 season $(55.7 \%$ of global production). However, sugar cane remains the country's main raw material (CONAB, 2019), which can create a critical dependence on this input.

Low-quality paddy rice and the by-product gathered from the pre-cleaning can be considered for ethanol production, after its hydrolysis that allows the formation of reducing sugar and the subsequent alcoholic fermentation (RAUL et al., 2016). The high content of starch and fiber of those by-products can render their transformation into fermentable sugars technically and economically feasible.

The enzymatic hydrolysis of starch and fibers results in higher conversion into sugar than the acid hydrolysis process (FERREIRA et al., 2013). The selective action of the enzyme on the molecule is the key factor for this result. Cellulase acts selectively on the fiber, while amyloglucosidase and alpha-amylase act only on starch, under specific conditions of $\mathrm{pH}$, temperature, concentration and reaction time; reducing the formation of secondary products (BISSWANGER, 2014).

Starch is composed of two polysaccharides: amylose and amylopectin and its hydrolysis produce oligosaccharides, dextrins and glucose (ECKERT et al., 2018). For fibers, cellulose hydrolysis generates glucose and cellobiose, and hemicellulose degradation produces arabinose, xylose, mannose, rhamnose, galactose and glucose (BALAT, 2011).

The objective was to evaluate the technical feasibility of the use of pre-cleaning residue and paddy rice type III as raw materials for ethanol production from enzymatic hydrolysis.

\section{MATERIALS AND METHODS}

\section{Sample preparation}

The pre-cleaning residue $(\mathrm{PCR})$ and the paddy rice classified as type III (PRT3) were obtained from a rice processing plant located in Lagoa da Confusão, State of Tocantins, Brazil. Pampeira and IRGA 425 cultivars comprised the samples.

Samples were dried in an oven operating by forced circulation of air (Model SL-102, Solab) at $60{ }^{\circ} \mathrm{C}$ for $48 \mathrm{~h}$ (INSTITUTO ADOLFO LUTZ, 2018). After drying, samples were crushed and sieved at 1 $\mathrm{mm}$ in a knife mill (Model MA 340, Marconi). The prepared material was stored in sealed containers prior to being analyzed and hydrolyzed.

\section{Proximate analysis}

The proximate analysis was performed for both by-products (PCR and PRT3) according to the AOAC international standards (AOAC, 2000), for the following parameters: Moisture (AOAC 934.01), ash (AOAC 924.05), crude fat (AOAC 920.39C) and crude protein (AOAC 920.87), using the conversion factor of 6.25 . Total fiber and lignin content were determined by the dietary fiber method (VAN SOEST et al., 1991) and the starch content by the Fehling method (AOAC, 2016). Cellulose concentration was estimated using the difference of total fiber, lignin content and the neutral detergent fibers - NDF.

The non-fibrous carbohydrate content was estimated by equation 1 (SNIFFEN et al., 1992).

$N F C=100-(C P+C F+A S H+T F)$

where:

$\mathrm{NFC}=$ Non-Fibrous Carbohydrates $(\%)$;

$\mathrm{CP}=$ Crude protein $(\%)$;

$\mathrm{CF}=$ Crude Fat $(\%)$;

$\mathrm{ASH}=\mathrm{Ash}(\%)$

$\mathrm{TF}=$ Total fibres $(\%)$.

\section{Pre-treatment of samples}

Once both by-products were characterized, a part of the samples of PCR and PRT3 were submitted to the pre-treatment to break its fibers. It aimed the 
hydrolysis of the lignocellulosic complex for the exposure of the cellulose molecules to the action of the specific enzymes. To do so, $10 \mathrm{~g}$ of sample was added in $100 \mathrm{~mL}$ of $0.1 \mathrm{Mol} . \mathrm{L}^{-1} \mathrm{NaOH}$ solution and then autoclaved (vertical AV analog model, Phoenix) for $1 \mathrm{~h}$ at $121{ }^{\circ} \mathrm{C}$. The samples were taken out from the autoclave and left to stand for $24 \mathrm{~h}$ at room temperature. The material was filtered and the solid portion retained in the filter was washed by distilled water until reaching $\mathrm{pH} 7.6$ at $26.1{ }^{\circ} \mathrm{C}$. Washed, the solid material was dried in an oven operating by forced circulation of air (Model SL-102, Solab) at 80 ${ }^{\circ} \mathrm{C}$ for $30 \mathrm{~h}$ (SUKUMARAN et al., 2009).

After pre-treatment, lignin (VAN SOEST et al., 1991) and starch contents were determined based on the Fehling method (AOAC, 2016) in order to evaluate the pre-treatment efficiency for lignin removal.

The remaining part of the samples, which were not submitted to pre-treatment, was taken to enzymatic hydrolysis and the consequent production of reducing sugars by the action of enzymes: alphaamylase (StarMax $300^{\circledR}$ ), amyloglucosidase (StarMax GA $300^{\circledR}$ ) and cellulase (CeluMax $C^{\circledR}$ ), produced and marketed by PROZYN ${ }^{\circledR}$. As the environmental and the medium conditions, such as $\mathrm{pH}$, temperature (T) and concentration (E) strongly influence the efficiency of the enzymatic process, they were set during a pretest stage.

\section{Enzymatic hydrolisys}

Once ideal values for $\mathrm{pH}$, temperature and concentration were determined, the samples were submitted to hydrolysis. The three enzymes were tested, individually, to set the optimal time of reaction. Yields were determined at $24 \mathrm{~h}, 48 \mathrm{~h}$ and $72 \mathrm{~h}$ from the beginning of reaction for cellulase and amyloglucosidase and after 90, 120 and 150 minutes for alpha-amylase. The range for reaction times and for the chemical-physical characteristics of the medium, were set based on the guidelines from the enzyme technical sheet.

The part of the samples that were hydrolyzed by the action of each enzyme at a time were submitted to the following procedure: $20 \mathrm{~g}$ of untreated sample was added to $0.4 \%$ of cellulase diluted in $50 \mathrm{~mL}$ of sodium acetate buffer solution. The $\mathrm{pH}$ of buffer solution was stabilized in 5.0. The mixture of the solution, cellulase and sample was placed inside a water bath and stirred for $48 \mathrm{~h}$ at $50{ }^{\circ} \mathrm{C}$. After cellulase acted over samples, $50 \mathrm{~mL}$ of sodium acetate buffer solution ( $\mathrm{pH} 4.5)$ and $0.1 \%$ of amyloglucosidase was added to the mixture. It stirred again this mixture in a water bath for $24 \mathrm{~h}$ at $58{ }^{\circ} \mathrm{C}$. Finally, the mixture received $0.3 \%$ of the alpha-amylase diluted in $50 \mathrm{~mL}$ of phosphate buffer solution (pH 6.0) and it was stirred in the water bath at $90{ }^{\circ} \mathrm{C}$, for 90 minutes.

As each enzyme is highly specific and its optimal performance can occur at conditions close to those for another enzyme, the reducing sugar yield was also tested for cellulase and amyloglucosidase acting simultaneously, in order to reduce the total reaction time, optimizing the process.

For the analysis of the simultaneous activity of the cellulase and amyloglucosidase followed by the alpha-amylase action, $0.4 \%$ of cellulase and $0.1 \%$ of amyloglucosidase were diluted in $50 \mathrm{~mL}$ of sodium acetate buffer solution ( $\mathrm{pH} 4.5)$ which received $20 \mathrm{~g}$ of no-pretreated sample. This mixture was stirred in a water bath for $48 \mathrm{~h}$ at $60{ }^{\circ} \mathrm{C}$ followed by the addition of $0.3 \%$ of alpha-amylase enzyme diluted in $50 \mathrm{~mL}$ of phosphate buffer solution ( $\mathrm{pH}$ 6.0), which was stirred in a water bath at $90{ }^{\circ} \mathrm{C}$ for 90 minutes.

After each reaction time for the individual or simultaneous action of enzymes, 2 $\mathrm{mL}$ of hydrolysate was taken out. $2 \mathrm{~mL}$ of $\mathrm{NaOH}$ $0.05 \mathrm{Mol} . \mathrm{L}^{-1}$ was added to hydrolysate for enzyme inactivation. This inactivated hydrolysate was centrifuged (Model 206, Fanem) at $3600 \mathrm{rpm}$ for 10 min and the supernatant was used to determine the reducing sugars content by 3.5-dinitrosalicylic acid - DNS method (MILLER, 1959).

The efficiency of the hydrolysis process for amyloglucosidase and alpha-amylase was calculated by equation 2 (KOWALSKI et al., 2017) and for cellulase by equation 3 (ANDRADE et al., 2019):

$\eta=\frac{[\text { Glu }]}{[S t c]} f s .100$

where:

$\eta$ : hydrolysis yield (\%);

[Glu]: glucose concentration (\%);

[Stc]: starch concentration (\%);

fs: conversion factor for starch (1.11).

$\eta=\frac{[\mathrm{Glu}]}{[\mathrm{Cel}]} f c .100$

where:

$\eta$ : hydrolysis yield (\%);

[Gli]: glucose concentration (\%);

[Cel]: cellulose concentration $(\%)$;

fc: conversion factor for celulose (0.9).

The total reducing sugar concentration obtained after the hydrolysis of fiber and starch was analyzed for each fraction: arabinose, cellobiose, 
galactose, glucose, mannose, xylose and sucrose. The individual sugar concentrations were determined by high-performance liquid chromatography (HPLC) using a refractive index (RI) detector, according to AOAC 977.20 (AOAC, 2016).

\section{Statistical analysis}

The data from proximate analysis were submitted to descriptive statistics. Other data were submitted to the normality test followed by ANOVA. The means were compared by the Tukey's test. All statistical procedures were performed by Action Stat Pro software (ESTATCAMP, 2017).

\section{RESULTS}

The proximate analysis of PCR revealed that $48.60 \%$ of the material are non-fibrous carbohydrates; $30.44 \pm 0.90 \%$ represented total fibers, being $11.50 \%$ cellulose; $9.63 \pm 0.23 \%$ of crude protein; $5.92 \pm 0.36 \%$ of crude fat; $5.91 \pm 0.25 \%$ of moisture and $5.41 \pm 0.39 \%$ of ash.

The results for PRT3 shows $59.73 \%$ of non-fibrous carbohydrates; $23.39 \pm 0.86 \%$ of total fibers, of which $8.34 \%$ are cellulose; $7.40 \pm 0.13 \%$ of moisture; $7.18 \pm 0.49 \%$ of crude protein; $6.56 \pm$ $0.27 \%$ of crude fat and $3.14 \pm 0.11 \%$ of ash.

The alkaline pre-treatment reduced $47.94 \%$ of the lignin content of PCR samples and $18.60 \%$ of PRT3. But 77.76 and $75.55 \%$ of starch were also removed from PCR e PRT3, respectively, by the alkaline pre-treatment (Table 1).

The optimal values of $\mathrm{pH}$, temperature (T) and concentration (E) for enzymatic hydrolysis using cellulase, amyloglucosidase and alpha-amylase did not differ among PCR and PRT3 (Table 2).

The time of exposure to some enzymes influenced the conversion rate of carbohydrates into reducing sugar for both by-products. The influence of time was observed for cellulase and for alphaamylase, not for amyloglucosidase. For cellulase, the best results for reducing sugar yields were achieved at a time of reaction of $48 \mathrm{~h}$. For alphaamylase, the optimal time was $90 \mathrm{~min}$, and $24 \mathrm{~h}$ for amyloglucosidase (Table 3).

Amyloglucosidase was responsible for most of the reducing sugar produced during the hydrolysis using one enzyme at a time, followed by alpha-amylase and cellulase, likewise for the hydrolysis efficiency. The yields calculated for the simultaneous action of amyloglucosidase and cellulase were lower than the results of its isolated action (Table 4).

The concentration of total reducing sugar was higher for the hydrolysis by the separate enzymes (Figure 1) and glucose was the only sugar retrieved from the enzymatic hydrolysis of starch and fiber from PCR and PRT3 (Table 5).

\section{DISCUSSION}

The starch content determines the feasibility of a raw material to get good yields from its hydrolysis and subsequent fermentation for ethanol production. Concentrations of $41.18 \%$ in PCR and $53.41 \%$ in PRT3 qualifies these by-products for ethanol production, since other traditionally used raw materials such as maize, sorghum and cassava have 67,70 and $85 \%$ starch, respectively (HILL, et al., 2012; SOARES et al., 2017; URBANO et al., 2017). Further, ethanol production may be greater if fibers can be converted into reducing sugars too, after hydrolysis of these polysaccharides (RAELE et al., 2014).

The proximate analysis of PCR shows similar results found for other rice strains, grown in different Brazilian regions (KAMINSKI et al., 2013; AMAGLIANI et al., 2017). Therefore, these results

Table 1 - Lignin and starch contents (Mean \pm SD g/100g) for pre-cleaning residue (PCR) and for type III paddy rice (PRT3) before and after pre-treatment.

\begin{tabular}{|c|c|c|c|c|}
\hline \multirow[t]{2}{*}{ Compounds } & \multicolumn{2}{|c|}{ 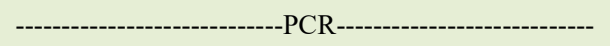 } & \multicolumn{2}{|c|}{ 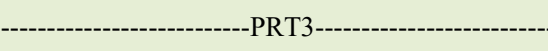 } \\
\hline & Before & After & Before & After \\
\hline Lignin & $6.53 \pm 0.45 \mathrm{a}$ & $3.40 \pm 0.24 b$ & $4.41 \pm 0.18 \mathrm{~A}$ & $3.59 \pm 0.22 \mathrm{~B}$ \\
\hline Starch & $41.18 \pm 0.69 \mathrm{a}$ & $9.16 \pm 0.32 b$ & $53.41 \pm 1.04 \mathrm{~A}$ & $13.06 \pm 0.39 \mathrm{~B}$ \\
\hline
\end{tabular}

*Means followed by the same letters in the line do not differ by the $\mathrm{F}$ test at $\mathrm{p}<0.05$. 
Table 2 - Optimum pH, temperature (T) and enzyme concentration (E) for enzymes.

\begin{tabular}{lccc}
\hline Enzyme & $\mathrm{pH}$ & $\mathrm{T}\left({ }^{\circ} \mathrm{C}\right)$ & $\mathrm{E}(\%)$ \\
\hline Cellulase & 5,0 & 50.0 & 0.4 \\
Amyloglucosidase & 4,5 & 58.0 & 0.1 \\
Alpha-amylase & 6,0 & 90.0 & 0.3 \\
\hline
\end{tabular}

can be replicated for other producing regions in Brazil or perhaps in the world. However, it must be considered that there are many materials that are part of PCR and it can vary among different processing plants, such as leaves, bark, soil, other parts of the plant and so on. Therefore, its chemical composition may be different depending on the cultivar, harvest time, weather conditions or processing procedures.

The reduction in lignin content via alkaline pre-treatment indicates the rupture of the lignocellulosic complex (KIM, et al., 2016). Similar results for delignification of rice husk and straw were presented by other authors (AZEVEDO et al., 2016, TAKANO \& HOSHINO, 2018). The highest reduction for lignin content in PCR samples is due to the presence of layers of silica, constituting a kind of shield that prevents the action of alkali (MARIN et al., 2015). Conversely, the pre-treatment caused an undesired effect, by reducing the starch content once hydrolyzed with alkali. It minimizes the yield of reducing sugar, so the use of pre-treatment was not recommended for the tested by-products.
Cellulase is an enzymatic complex that acts in synergism, so the hydrolysis process required a longer reaction time. However, if glucose and cellobiose formed by hydrolysis remained in the same medium for a long time, they inhibited the action of cellulase, decreasing the reducing sugar concentrations (SINGH, et al., 2014).

Hydrolysis by amyloglucosidase can occur for long periods, since it acts on the non-reducing end, breaking both connections: $\alpha-1,4$ and $\alpha-1,6$ (TORRES, et al., 2012). Conversely, alpha-amylases hydrolyze starch faster, as these enzymes only break the $\alpha-1.4$ bonds along the amylose and amylopectin chains (TORRES et al., 2012). Most enzymes produced by bacteria are stable at $90^{\circ} \mathrm{C}$, but they lose stability over time, which may decrease their activity (KHAWLLA et al., 2014).

A higher relation between starch and fibers concentrations, and the occurrence of lignin that hinders enzymatic access to cellulose (CASTRO et al., 2017), explains the higher conversion rate into reducing sugar by the action of amylolitic enzymes (TORRES et al., 2012).

The higher efficiency of amyloglucosidase can be justified by the high concentration of amylopectin compared to amylose in rice (DENARDIN et al., 2012). However, the lower reducing sugar yield for simultaneous hydrolysis is due to the $\mathrm{pH}$ and the temperature of the medium. They were adjusted to an intermediary condition for both enzymes, as close as possible to the optimal values, but it may reduce enzymatic activity (BISSWANGER, 2014). For cellulase, the reducing

Table 3 - Reducing sugar concentration $\left(\mathrm{mg} \cdot \mathrm{mL}^{-1}\right)($ Mean $\pm \mathrm{SD})$ after enzymatic hydrolysis by cellulase, amyloglucosity and alphaamylase at different reaction times.

\begin{tabular}{|c|c|c|c|c|c|c|}
\hline \multirow[t]{2}{*}{ Enzyme } & \multicolumn{6}{|c|}{ 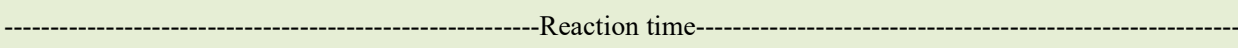 } \\
\hline & $90 \mathrm{~min}$ & $120 \mathrm{~min}$ & $150 \mathrm{~min}$ & $24 \mathrm{~h}$ & $48 \mathrm{~h}$ & $72 \mathrm{~h}$ \\
\hline & & 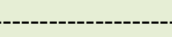 & --PCR----------- & ---------------' & --------------- & 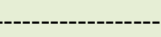 \\
\hline Cellulase & N.A. & N.A. & N.A. & $2.02 \pm 0.53 \mathrm{~b}$ & $3.51 \pm 0.48 \mathrm{a}$ & $2.33 \pm 0.19 \mathrm{~b}$ \\
\hline Amyloglucosidas & N.A. & N.A. & N.A. & $37.37 \pm 1.50 \mathrm{a}$ & $37.19 \pm 0.23 \mathrm{a}$ & $36.87 \pm 0.76 \mathrm{a}$ \\
\hline Alpha-amylase & $17.51 \pm 0.48 \mathrm{a}$ & $16.33 \pm 0.19 \mathrm{~b}$ & $16.037 \pm 0.26 \mathrm{~b}$ & N.A. & N.A. & N.A. \\
\hline & & & --PRT3---------. & - & - & - \\
\hline Cellulase & N.A. & N.A. & N.A. & $2.74 \pm 0.17 \mathrm{~b}$ & $3,78 \pm 0.08 \mathrm{a}$ & $2.71 \pm 0.10 \mathrm{~b}$ \\
\hline Amyloglucosidas & N.A. & N.A. & N.A. & $25.50 \pm 0.41 \mathrm{a}$ & $25.28 \pm 0.21 \mathrm{a}$ & $25.09 \pm 0.12 \mathrm{a}$ \\
\hline Alpha-amylase & $12.70 \pm 0.52 \mathrm{a}$ & $11.24 \pm 0.18 \mathrm{~b}$ & $11.07 \pm 0.27 \mathrm{~b}$ & N.A. & N.A. & N.A. \\
\hline
\end{tabular}

"Means followed by the same letters in the line do not differ by the Tukey's test at $\mathrm{p}<0.05$.

${ }^{* *}$ NA - Does not apply. 
Table 4 - Reducing sugar (SC) and efficiency $(\eta)$ for hydrolysis by cellulase, amyloglucosidase, alpha-amylase, and simultaneously by cellulose plus amyloglucosidase.

\begin{tabular}{lcccc}
\hline Enzymes & SC (\%) & & & \\
& & & & \\
& & & & \\
Cellulase $(\%)$ & $(\%)$ & $1.42 \pm 0.23$ & \\
Amyloglucosidase & $2.89 \pm 0.21$ & 22.61 & $35.28 \pm 3.34$ & 59.67 \\
Alpha-amylase & $25.49 \pm 2.06$ & 56.30 & $16,26 \pm 6.43$ & 27.40 \\
Amyl + Cellulase & $11.72 \pm 2.89$ & 25.88 & $25.11 \pm 1.08$ & N.A. \\
\hline
\end{tabular}

NA - Not applicable (reducing sugar content comes from starch and cellulose).

sugar yield was lower due to the low concentration of cellulose in the tested by-products, that results in the dispensable use of this enzyme for ethanol production using the rice by-products.

The absence of arabinose, galactose, xylose and mannose in sugar analysis demonstrated that hemicellulose was not degraded (Balat, 2011). Since the action of enzymes is specific, the environmental and the medium conditions were not sufficient for the hydrolysis of the hemicellulose.

The cellobiose formed by cellulose hydrolysis was degraded into glucose by the action

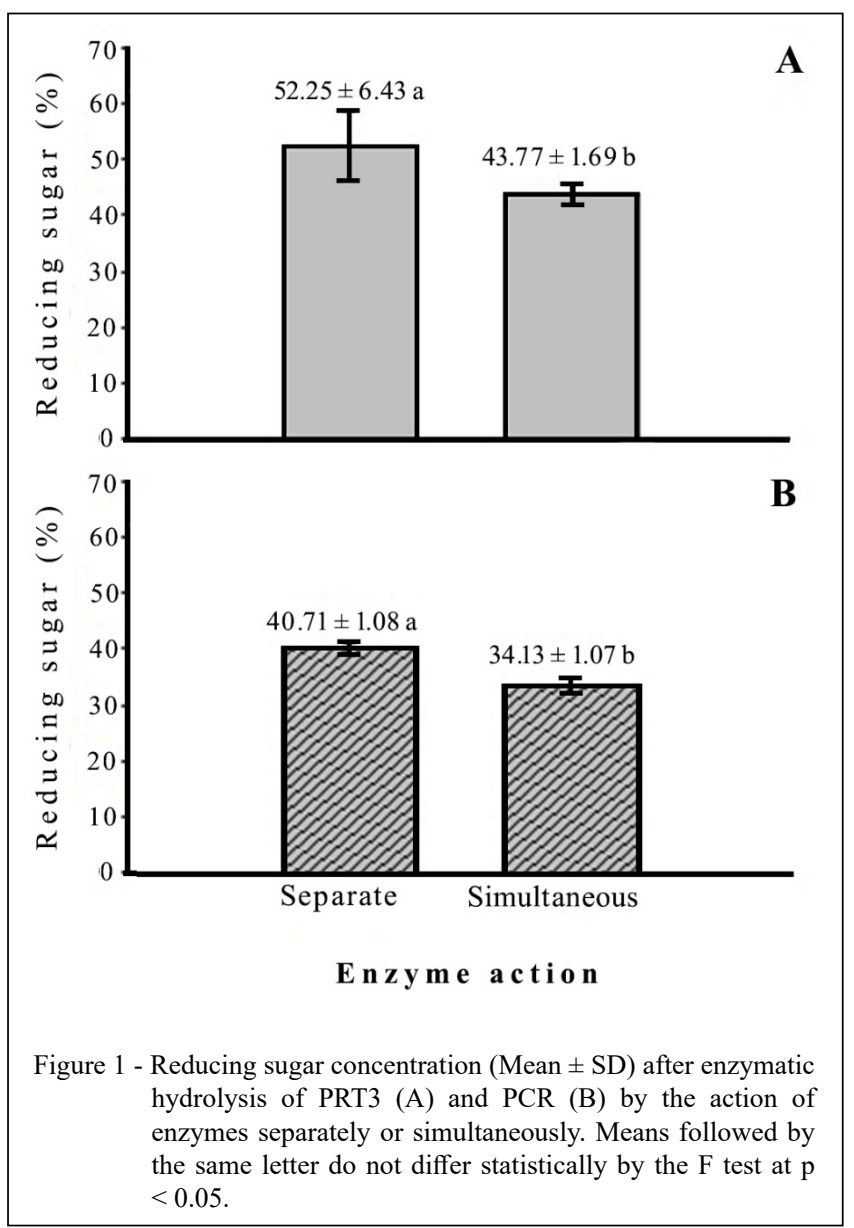

Ciência Rural, v.51, n.11, 2021. 
Table 5 - Sugars concentration of hydrolyzed samples, determined by HPLC-RI.

\begin{tabular}{|lcc|}
\hline Sugars & PCR & PRT3 \\
\hline & ND & ND \\
\hline Arabinose & ND & ND \\
\hline Celobiose & ND & ND \\
\hline Galactose & 36.25 & 49.26 \\
\hline Glucose & ND & ND \\
Manose & ND & ND \\
Xylose & ND & ND \\
\hline Sucrose & & \\
\hline
\end{tabular}

ND - Not Detected.

of $\beta$-glucosidase that compose the enzymatic complex (ODEGA \& PETRI, 2010). The action of amylolitic and cellulolytic enzymes on the material was confirmed by the exclusive presence of glucose in the hydrolysate, which may increase the yield of alcoholic fermentation by Saccharomyces $s p$. yeasts.

\section{CONCLUSION}

Alkaline pre-treatment was effective for lignin reduction but caused the loss of a part of the starch in by-products. Therefore, the use of non-pretreated by-products ensures higher sugar concentrations for ethanol production.

Enzymatic hydrolysis using one enzyme at a time presented a higher yield in reducing sugars. Acting simultaneously, the enzymes had its action influenced by the $\mathrm{pH}$ and the temperature. Optimum temperature, $\mathrm{pH}$, concentration and time of reaction can increase the performance of enzymatic hydrolysis of rice by-products.

The use of amyloglucosidase and alphaamylase to hydrolyze pre-cleaning residue and lowquality paddy rice can make feasible the use of these by-products for ethanol production. As a result, increasing the diversity of sustainable raw materials can supply this fuel chain.

\section{ACKNOWLEDGEMENTS}

We thank the technical and financial support of Evidência Agrícola Ltda and of Universidade Federal do Mato Grosso - Campus of Sinop.

\section{DECLARATION OF CONFLICT OF INTEREST}

The authors declare no conflict of interest. The founding sponsors had no role in the design of the study; in the collection, analyses, or interpretation of data; in the writing of the manuscript, and in the decision to publish the results.

\section{AUTHORS' CONTRIBUTIONS}

All authors contributed equally for the conception and writing of the manuscript. All authors revised the manuscript and approved the final version.

\section{REFERENCES}

AMAGLIANI, L. et al. The composition, extraction, functionality and applications of rice proteins: A review. Trends in Food Science \& Technology, 64, 1-12, 2017. Available from: <http:// dx.doi.org/10.1016/j.tifs.2017.01.008>. Accessed: Apr. 17, 2019. doi: 10.1016/j.tifs.2017.01.008.

ANDRADE, T. C. C. et al. Enzymatic Cellulose Hydrolysis for Glucose Obtainment Using Ionic Liquid as a Solvent Medium Revista Virtual Química, 11, 310-325, 2019. Available from: $<$ https://doi.org/10.21577/1984-6835.20190022>. Accessed: Apr. 19, 2019. doi: 10.21577/1984-6835.20190022.

AOAC - Association of Official Analytical Chemists. 2000 Official methods of analysis of the Association of the Analytical Chemists. 17th ed. Virginia, 2000.

AOAC - Association of Official Analytical Chemists. Official methods of analysis of the Association of the Analytical Chemists. 20th ed. Maryland/USA, 2016.

AZEVEDO, V. Q. et al. Characterization of biomass aiming second generation ethanol production. Revista Brasileira de Engenharia e Sustentabilidade, 2, 61-65, 2016. Available from: $<$ https://doi. org/10.18540/2446941603032017561>. Accessed: May, 15, 2019. doi: $10.18540 / 2446941603032017561$.

BALAT, M. Production of bioethanol from lignocellulosic materials via the biochemical pathway: A review. Energy Conversion and Management, 5, 858-875, 2011. Available from: <http://dx.doi. org/10.1016/j.enconman.2010.08.013>. Accessed: Oct. 25, 2019. doi: 10.1016/j.enconman.2010.08.013.

BISSWANGER, H. Enzyme assays. Perspectives in Science, 1, s41-55, 2014. Available from: < http://dx.doi.org/10.1016/j. pisc.2014.02.005>. Accessed: Jun. 16, 2019. doi: 10.1016/j. pisc.2014.02.005.

BRASIL Ministério da Agricultura, Pecuária e Abastecimento. Instrução normativa $\mathrm{N}^{\circ}$ 6, de 16 de fevereiro, 2009.

CASTRO, B.G.F. et al. Alkaline deacetylation as a strategy to improve sugars recovery and ethanol production from rice straw hemicellulose and cellulose. Industrial Crops and Products, 106, 65-73, 2017. Available from: <http://dx.doi.org/10.1016/j. indcrop.2016.08.053>. Accessed: Apr. 17, 2019. doi: 10.1016/j. indcrop.2016.08.053.

CONAB. Cana de açúcar. Acompanhamento da safra brasileira. v.6. n.3. 2019. Available from: < https://www.conab.gov.br/infoagro/safras/cana>. Accessed: Jan. 25, 2020.

DENARDIN, C. C. et al. Amylose content in rice (Oryza sativa) affects performance, glycemic and lipidic metabolism in rats. Ciência Rural, Santa Maria 42, 2381-387, 2012. Available from: <http://

Ciência Rural, v.51, n.11, 2021. 
dx.doi.org/10.1590/S0103-84782012005000002>. Accessed: May, 30, 2019. doi: 10.1590/S0103-84782012005000002.

ECKERT, C. T. et al. Maize ethanol production in Brazil: Characteristics and perspectives. Renewable and Sustainable Energy Reviews, 82, 3907-3912, 2018. Available from: <https:// doi.org/10.1016/j.rser.2017.10.082>. Accessed: Aug. 01, 2019. doi: 10.1016/j.rser.2017.10.082

ESTATCAMP. Action Stat Pro. Version 3.1. São Carlos-SP. Brazil: Estatcamp - Consultoria Estatística e Qualidade; 2017.

FERREIRA, S. M. et al. Production of reducing sugars by acid and enzimatic hydrolysis of broken rice flour. Revista Brasileira de Produtos Agroindustriais, 15, 383-390, 2013. Available from: <https://doi.org/10.15871/1517-8595/rbpa.v15n4p383-390> Accessed: Jun. 16, 2019. doi: 10.15871/1517-8595/rbpa. v15n4p383-390.

FAO - Food and Agriculture Organization of the United Nations. Rice market monitor. v.XXI, n.1, 2018. Available from: $<$ http:// www.fao.org/3/19243EN/i9243en.pdf>. Accessed: Oct. 19, 2019.

HALBERSTADT, K. F. et al. Sustainable practices on waste resulting from the production rice Revista Eletrônica em Gestão, Educação e Tecnologia Ambiental, Santa Maria, v.19, p.298-312, 2015. Available from: <http://dx.doi. org/10.5902/2236117015816>. Accessed: Feb. 10, 2019. doi: $10.5902 / 2236117015816$.

HILL, H. et al. Variation in sorghum starch synthesis genes associated with differences in starch phenotype. Food Chemistry, 131, 175-183, 2012. Available from: <http://dx.doi.org/10.1016/j. foodchem.2011.08.057>. Accessed: Feb. 10, 2019. doi: 10.1016/j. foodchem.2011.08.057.

IBGE - Instituto Brasileiro de Geografia e Estatística. Levantamento sistemático da produção agrícola - dezembro 2018. 2019. Available from: -<https://sidra.ibge.gov.br/home/lspa/ brasil>. Accessed: Oct. 19, 2019.

INSTITUTO ADOLFO LUTZ. Métodos físicos-químicos para análise de alimentos. São Paulo: Instituto Adolfo Lutz, 2008.

IPEA - Instituto de Pesquisa Econômica Aplicada. Diagnósticos dos resíduos orgânicos do setor agrossilvopastoril e agroindústrias associadas. Relatório de Pesquisa, setembro, 2012. Available from: <http://www.ipea.gov.br/portal/index. php?option=com_content\&view $=$ article $\&$ id $=15493 \&$ catid $=222 \&$ I temid $=7>$. Accessed: Jan. 12, 2020.

KAMINSKI, T. A. et al. Chemical composition and structural changes of irrigated rice during storage. Semina: Ciências Agrárias, v.34, p.1167-1184, 2013. Available from: $<\mathrm{http}: / / \mathrm{dx}$.doi. org/10.5433/1679-0359.2013v34n3p1167>. Accessed: May, 20, 2019. doi: 10.5433/1679-0359.2013v34n3p1167.

KHAWLLA, B. J. et al. Potato peel as feedstock for bioethanol production: A comparison of acidic and enzymatic hydrolysis. Industrial Crops and Products, 52, 144-149, 2014. Available from: $\quad<$ http://dx.doi.org/10.1016/j.indcrop.2013.10.025>. Accessed: Apr. 17, 2019. doi: 10.1016/j.indcrop.2013.10.025.

KIM, J. S.; et al. A review on alkaline pretreatment technology for bioconversion of lignocellulosic biomass. Bioresource Technology, 199, 42-48, 2016. Available from: <http://dx.doi. org/10.1016/j.biortech.2015.08.085>. Accessed: Apr. 16, 2019. doi: 10.1016/j.biortech.2015.08.085.

KOWALSKI, R. L. et al. Production of second generation ethanol from avocado seed (Persea americana Mill.) Revista Brasileira de Energias Renováveis, 6, 665-677, 2017. Available from: <http:// dx.doi.org/10.1017/CBO9781107415324.004>. Accessed: Jul. 16, 2019. doi: $10.1017 / \mathrm{CBO} 9781107415324.004$.

MARIN, D. C. et al. Revalorization of rice husk waste as a source of cellulose and silica. Fibers and Polymers, 16, 285-293, 2015. Available from: <http://dx.doi.org/10.1007/s12221-015-0285-5>. Accessed: Nov. 17, 2019. doi: 10.1007/s12221-015-0285-5.

MILLER, G. L. Use of dinitrosalicylic acid reagent for determination of reducing sugar. Analytical Chemistry, 31, 426-428, 1959. Available from: <http://dx.doi.org/10.1021/ac60147a030>. Accessed: Sept. 15, 2019. doi: 10.1021/ac60147a030.

NASCIMENTO FILHO, W. B.; FRANCO, C. R. Potential Assessment of Waste Produced Through the Agro-Industrial Processing in Brazil. Revista Virtual de Química, 7, 19681987, 2015. Available from: <http://dx.doi.org/10.5935/19846835.20150116> Accessed: Mar. 20, 2019. doi: 10.5935/19846835.20150116

NONES, D. L. et al. Quantification of agricultural and forestry waste biomass to production of compacts for power generation. Revista de Ciências Agroveterinárias, 16, 155-164, 2017. Available from: <http://dx.doi.org/10.5965/223811711622017155 >. Accessed: Apr. 17, 2019. doi: 10.5965/223811711622017155.

ODEGA, T. L.; PETRI, D.F.S. Biomass Enzymatic Hydrolysis. Química Nova, 33, 1549-1558, 2010. Available from: <https://doi. org/10.1590/S0100-40422010000700023>. Accessed: May, 10, 2019. doi: 10.1590/S0100-40422010000700023.

RAELE, R. et al. Scenarios for the second generation ethanol in Brazil. Technological Forecasting and Social Change, 87, 205-223, 2014. Available from: <http://dx.doi.org/10.1016/j. techfore.2013.12.010>. Accessed: Dec. 02, 2019. doi: 10.1016/j. techfore.2013.12.010

RAUL, J. et al. Enzymatic saccharification and fermentation of rice processing residue for ethanol production at constant temperature. Biosystems Engineering, 42, 110-116, 2016. Available from: $<$ http://dx.doi.org/10.1016/j.biosystemseng.2015.12.013>. Accessed: Mar. 03, 2019. 10.1016/j.biosystemseng.2015.12.013.

SINGH, A. et al. Enzymatic hydrolysis of microwave alkali pretreated rice husk for ethanol production by Saccharomyces cerevisiae, Scheffersomyces stipitis and their co-culture. Journal Fuel, 116, 699-702, 2014. Available from: <http://dx.doi. org/10.1016/j.fuel.2013.08.072>. Accessed: Oct. 01, 2019. doi: 10.1016/j.fuel.2013.08.072.

SNIFFEN, C. J. et al. A net carbohydrate and protein system for evaluating cattle diets: II. Carbohydrate and protein availability. Journal of Animal Science, 70, 3562-3577, 1992. Available from: $<$ http://dx.doi.org/10.2527/1992.70113562x>. Accessed: Jan. 15, 2019. $10.2527 / 1992.70113562 x$.

SOARES, J. S.; ATUI, M. B.; MARCIANO, M. A. M.; LORINI, I. Microscopic analysis of the starch extracted from conventional and transgenic corn (Zea mays). Revista Instituto Adolfo Lutz, 76, 1718, 2017. Available from: <http://www.ial.sp.gov.br/resources/ 
insituto-adolfo-lutz/publicacoes/rial/10/rial76_completa/artigosseparados/1718.pdf>. Accessed: Feb. 08, 2019.

SUKUMARAN, R. K. et al. Cellulase production using biomass feed stock and its application in lignocellulose saccharification for bio-ethanol production. Renewable Energy, 34, 421-424, 2009. Available from: $<$ http://dx.doi.org/10.1016/j.renene.2008.05.008>. Accessed: Mar. 03, 2019. doi: 10.1016/j.renene.2008.05.008.

TAKANO, M.; HOSHINO, K. Bioethanol production from rice straw by simultaneous saccharification and fermentation with statistical optimized cellulase cocktail and fermenting fungus. Journal Bioresources and Bioprocessing, 5, 16, 2018. Available from: <http://dx.doi.org/10.1186/s40643-018-0203-y>. Accessed: Apr. 12, 2019.

TORRES, L. M., et al. Amylolitic enzymes concentration in the starch hydrolisis of ginger. Ciência Rural, Santa Maria 42, 327 1332, 2012. Available from: <http://dx.doi.org/10.1590/s010384782012005000043>. Accessed: Feb. 03, 2019. doi: 10.1590/ s0103-84782012005000043.
URBANO, L. H. et. al. Kinetic and fermentative study of cassava starch. Revista Raízes e Amidos Tropicais, 13, 46-55, 2017. Available from: $\quad<$ http://dx.doi.org/10.17766/1808-981X.2017v13n1p46-55>. Accessed: Mar. 18, 2019. doi: 10.17766/1808-981X.2017v13n1p46-55.

VAN SOEST, P. J.; et al. Methods for dietary fiber, neutral detergent fiber, and nonstarch polysaccharides in relation to animal nutrition. Journal of Dairy Science, 74, 3583-3597, 1991. Available from: $<$ http://dx.doi.org/10.3168/jds.S0022-0302(91)78551-2>. Accessed: Feb. 15, 2019. doi: 10.3168/jds.S0022-0302(91)78551-2.

WALTER, M. et al. Rice: composition and nutritional characteristics. Ciência Rural, Santa Maria v.38, p.1184-1192, 2008. Available from: <https://doi.org/10.1590/S0103-84782008000400049>. Accessed: Jul. 7, 2019. doi: 10.1590/S0103-84782008000400049.

ZIEGLER, V. et al. Effects of storage temperature of whole rice grains with brown, black and red pericarps, on the physicochemical and pasting properties. Brazilian Journal of Food Technology, v.20, e2016051, 2017. Available from: <http://dx.doi.org/10.1590/19816723.5116>. Accessed: Jul. 2, 2019. doi: 10.1590/1981-6723.5116. 